\title{
Adventitious Shoot Regeneration and Plant Production from Explants of Apios americana
}

\author{
E.R.M. Wickremesinhe, W.J. Blackmon, and B.D. Reynolds \\ Department of Horticulture, Louisiana Agricultural Experiment Station, \\ Louisiana State University Agricultural Center, Baton Rouge, LA 70803
}

Additional index words. tissue culture, groundnut, tuber, legume

Abstract. Shoots were regenerated from callus of Apios americana Medikus (apios, groundnut) using internodal explants from in vitro-germinated seedlings and from sprouted tubers on a modified Murashige and Skoog (MS) basal medium. Shoot regeneration was observed over a range of $2 \mathrm{iP}$ and IBA combinations. GA $\mathrm{A}_{3}$ increased the number of shoots regenerated per epicotyl explant. The most efficient regeneration $(\approx 90 \%)$ was with internodal epicotyl explants on $100 \mu \mathrm{M} 2 \mathrm{iP}, 0.5 \mu \mathrm{M} \mathrm{IBA}$, and 1.5 $\mu \mathrm{GA}_{3}$. Regenerated shoots were rooted on liquid and solid MS medium with 0.5 $\mu$ M IBA; however, rooting was more successful on the liquid medium. About $60 \%$ of rooted plants were successfully established in pots. Chemical names used: $N$ - (3-methyl2-butenyl)-1 $\mathrm{H}$ - purin-6-amine (2iP), $1 \mathrm{H}$ - indole-3-butanoic acid (IBA), gibberellic acid $\left(\mathbf{G ~ A} \mathbf{A}_{3}\right)$.

Apios americana (apios, groundnut) is being domesticated as a tuber crop for human consumption (Blackmon and Reynolds, 1986; Reynolds et al., 1990). It is a viny legume that is native to North America and was, at the time of arrival of the European explorers to the New World, an important food of the Indians (Beardsley, 1938; Woods, 1988).

The ability to propagate apios from both seeds and tubers adds a tremendous versatility to germplasm manipulation. The objective of this study was to develop an efficient tissue culture protocol for future use in generating and screening somaclonal variants.

Seeds were surface-sterilized in $5.25 \%$ sodium hypochlorite (100\% Clorox) for $15 \mathrm{~min}$, washed three times in sterile distilled water, placed individually in culture tubes containing $10 \mathrm{ml}$ of water agar (7\% TC agar), sealed with parafilm, and incubated under continuous light $\left(\approx 60 \mu \mathrm{mol} \cdot \mathrm{s}^{-1} \cdot \mathrm{m}^{-2}\right)$ at $26 \mathrm{C}$ for germination. Tubes with any indication of

Received for publication 7 Aug. 1989. The cost of publishing this paper was defrayed in part by the payment of page charges. Under postal regulations, this paper therefore must be hereby marked advertisement solely to indicate this fact. contamination were discarded. When seedlings were 10 to $20 \mathrm{~cm}$ long, the basal sections, shoot-tip regions, and nodes were excised and discarded. Care was taken to exclude sections less than $1 \mathrm{~cm}$ from all visible nodes to eliminate the inclusion of any existing meristematic regions that have been reported in some legumes (Kameya and Widholm, 1981). From the remaining 4- to 5-cm sections, 2-mm segments were excised and placed on appropriate media.

Tubers from the selection LA85-034 were washed in tap water, surface-sterilized by immersion in $2.6 \%$ sodium hypochlorite $(50 \%$ Clorox) for $10 \mathrm{~min}$, rinsed in tap water, and placed inside a $25 \times 32 \times 10-\mathrm{cm}$ clear plastic container. After tubers had sprouted and shoots were $\approx 15$ to $20 \mathrm{~cm}$ long, 10 -cm stem sections were obtained, exclusive of the basal and shoot-tip regions. Nodal sections of 2 to $4 \mathrm{~cm}$ were removed. The remaining stem internodal sections were placed in $0.5 \%$ sodium hypochlorite (10\% Clorox) for $10 \mathrm{~min}$, rinsed three times in sterile distilled water, and 2-mm segments were excised as explants and placed. on appropriate media.

All preliminary regeneration experiments were conducted with media series SIM-1 and SIM-3 (Table 1), and each treatment was 


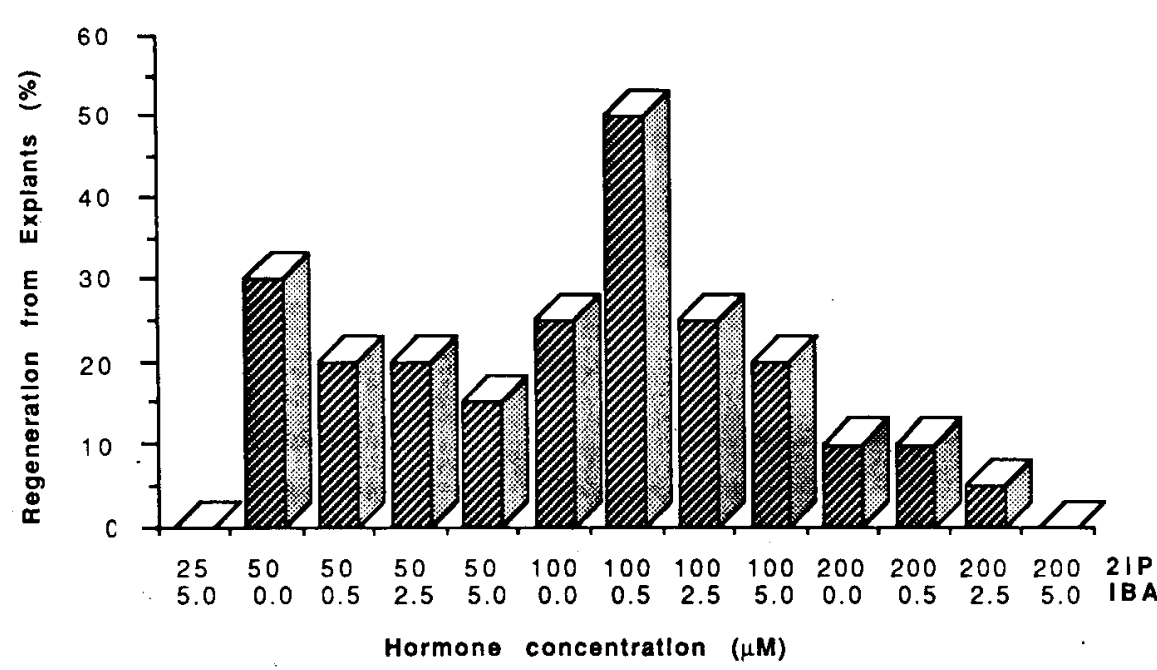

Fig. 1. Shoot regeneration from A. americana epicotyl internodal explants on the SIM-1 media series. No regeneration was observed for 0 and $25 \mu \mathrm{M} 2 \mathrm{iP}$ with IBA or $200 \mu \mathrm{M} 2 \mathrm{iP}+5.0 \mu \mathrm{M}$ IBA. Each treatment was replicated 20 times. Data were collected after 16 weeks in culture.

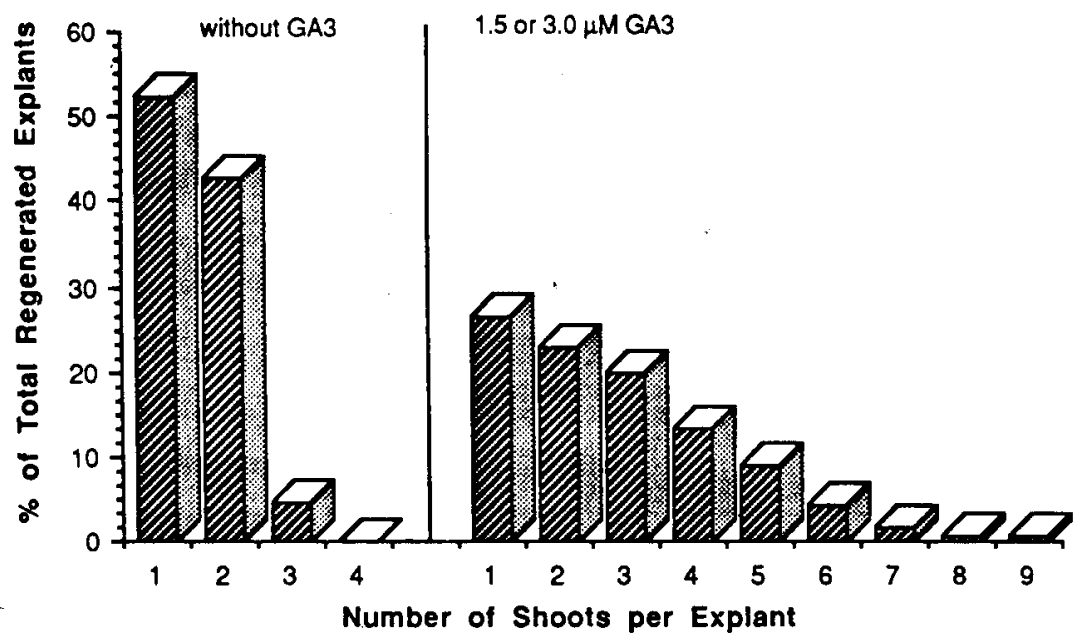

Fig. 2. Effects of $\mathrm{GA}_{3}$ on number of shoots per explant from epicotyl sections of $A$. americana on medium series SIM-2. Results with 1.5 and $3.0 \mu \mathrm{M} \mathrm{GA}$ were pooled.

Table 1. Composition of media used in regeneration and rooting experiments.

\begin{tabular}{|c|c|}
\hline Series designation ${ }^{2}$ & Constituents \\
\hline Basal media & \\
\hline SIB & $\begin{array}{l}\text { Murashige and Skoog (1962) salt base with (all in } \mathrm{mg} \cdot \mathrm{liter}^{-1} \text { ) } 500 \text { myo- } \\
\text { inositol, } 2 \text { thiamine } \cdot \mathrm{HCl}, 2 \mathrm{D} \text {-pantothenic acid, } 1 \text { nicotinic acid, } 1 \text { pyri- } \\
\text { doxine, } 4 \times 10^{4} \text { glucose, and } 7 \times 10^{3} \mathrm{TC} \text { agar }\end{array}$ \\
\hline SMB & $\begin{array}{l}\text { SIB }+(\text { in mg.liter }-1) 100 \text { instead of } 500 \text { myo-inositol and } 2 \times 10^{4} \text { sucrose } \\
\text { instead of } 4 \times 10^{4} \text { glucose }\end{array}$ \\
\hline \multicolumn{2}{|c|}{ Shoot regeneration media } \\
\hline SIM-1 & $\begin{array}{l}\mathrm{SIB}+(0,25,50,100 \text {, or } 200 \mu \mathrm{M}) 2 \mathrm{iP} \times(0.0,0.5,2.5 \text {, or } 5.0 \mu \mathrm{M}) \mathrm{IBA} \\
\quad+1.5 \mu \mathrm{M} \mathrm{GA}_{3}\end{array}$ \\
\hline SIM-2 & $\mathrm{SIB}+100 \mu \mathrm{M} 2 \mathrm{iP}+0.5 \mu \mathrm{M} \mathrm{IBA}+(0.0,1.5$, or $3.0 \mu \mathrm{M}) \mathrm{GA}_{3}$ \\
\hline SIM-3 & $\begin{array}{l}\mathrm{SIB}+(0,25,50,100,200, \text { or } 400 \mu \mathrm{M}) 2 \mathrm{iP} \times(0.0,0.5,2.5,5.0 \text {, or } 10.0 \\
\mu \mathrm{M}) \mathrm{IBA}+3.0 \mu \mathrm{M} \mathrm{GA}_{3}\end{array}$ \\
\hline \multicolumn{2}{|r|}{ (10) } \\
\hline RIB-1 & $\mathrm{SMB}+(0.0,0.5,2.5,5.0$, or $10.0 \mu \mathrm{M}) \mathrm{IBA}$ or NAA \\
\hline RIB-2 & SMB $+0.5 \mu \mathrm{M}$ IBA without agar \\
\hline
\end{tabular}

${ }^{2} \mathrm{~A}$ redundancy was maintained in the series to facilitate discussion of different experiments.

replicated 20 times. In subsequent experiments, based on the most effective hormone combinations, treatments were replicated 20 to 40 times, and experiments were repeated at least three times. Incubation was under a 16$\mathrm{hr}$ photoperiod with 80 to $90 \mu \mathrm{mol} \cdot \mathrm{s}^{-1} \cdot \mathrm{m}^{-2}$ hr photoperiod with 60 to $70 \mu \mathrm{mol} \cdot \mathrm{s}^{-1} \cdot \mathrm{m}^{-2}$ of cool-white fluorescent light at $\approx 26 \mathrm{C}$.

The $\mathrm{pH}$ of all media was adjusted to 5.7 with $1 \mathrm{~N} \mathrm{NaOH}$ or $1 \mathrm{~N} \mathrm{HCl}$ before autoclaving. Aliquots of $10 \mathrm{ml}$ for agar-containing media were dispensed into $25 \times 150-\mathrm{mm}$ culture tubes. For rooting experiments, 25 $\times 200-\mathrm{mm}$ culture tubes with $4 \mathrm{ml}$ of liquid medium were used. Tubes were covered with plastic caps (Kaputs; Bellco Glass, Vineland, N.J.) and autoclave for $15 \mathrm{~min}$ at $121 \mathrm{C}$.

Well-rooted shoots were dipped in a 250ppm solution of methyl[1-[(butylamino) carbonyl]-1 $H$ - benzymidazol-2-yl] carbamate (Benlate) and transferred to $130 \mathrm{ml}$ of an autoclave 1 perlite : 1 Pro Mix potting medium in $5 \times 5 \mathrm{~cm}$. The pots were placed inside $25 \times 32 \times 10$-cm clear plastic boxes and covered with similar boxes. Plants were watered regularly and fertilized with $15 \mathrm{~N}-30 \mathrm{P}-15 \mathrm{~K}$ ( $\left.5 \mathrm{~g} \cdot \mathrm{liter}^{-1}\right)$ once a week. The plants were also treated again with a 250-ppm Benlate solution 1 week later. All plants were maintained under incubation conditions similar to the regeneration protocol. After acclimatization, pots containing plants were transferred to the greenhouse.

The response of internodal epicotyl explants when placed on the SIM-1 media series (Table 1) is presented in Fig. 1. The combination of $100 \mu \mathrm{M} 2 \mathrm{iP}$ and $0.5 \mu \mathrm{M}$ IBA with $1.5 \mu \mathrm{M} \mathrm{GA}_{3}$ was superior $(P<0.01)$ to the other hormonal combinations for inducing regeneration. Although the presence of $\mathrm{GA}_{3}$ in the medium did not result in a significant increase $(P=0.85)$ in the mean number of epicotyl explants that regenerated shoots, either 1.5 or $3.0 \mu \mathrm{M} \mathrm{GA}_{3}$ in the media significantly $(P<0.01)$ increased the number of regenerated shoots per epicotyl explant (Table 2). In the absence of $\mathrm{GA}_{3}$, none of the epicotyl explants regenerated more than three shoots (Fig. 2). The effects of gibberellin on organogenesis and embryogenesis have been discussed (Thorpe, 1980). Williams and McHughen (1986) reported that $\mathrm{GA}_{3}$ was essential for regeneration of shoots from epicotyl explants of the legume Lens culinaris. Our study indicates that $\mathrm{GA}_{3}$ is also important for increasing the number of shoots regenerated per explant from epicotyl callus of A. americana.

The regeneration patterns of internodal explants from sprouted tubers were less definitive than those of epicotyl internodal explants (Fig. 1 vs. Fig. 3). When the five best treatments shown in Fig. 3 (2iP : IBA ratios of 50:5.0, 100:2.5, 100:5.0, 200:2.5, and 200:5.0) were tested further, regeneration percentages of $41.2 \%$ to $48.3 \%$ were observed, and the individual shoot regeneration responses of the explants to the five treatments were not significantly $(P=0.77)$ different. The number of shoots regenerated per explant ranged from one to three for all treatments, with an overall mean of 1.14 (data not shown).

In preliminary experiments using SIM-3 media series, shoots were also produced from leaf and petiole explants from in vitro-germinated seedlings, leaf explants from in vitro- 


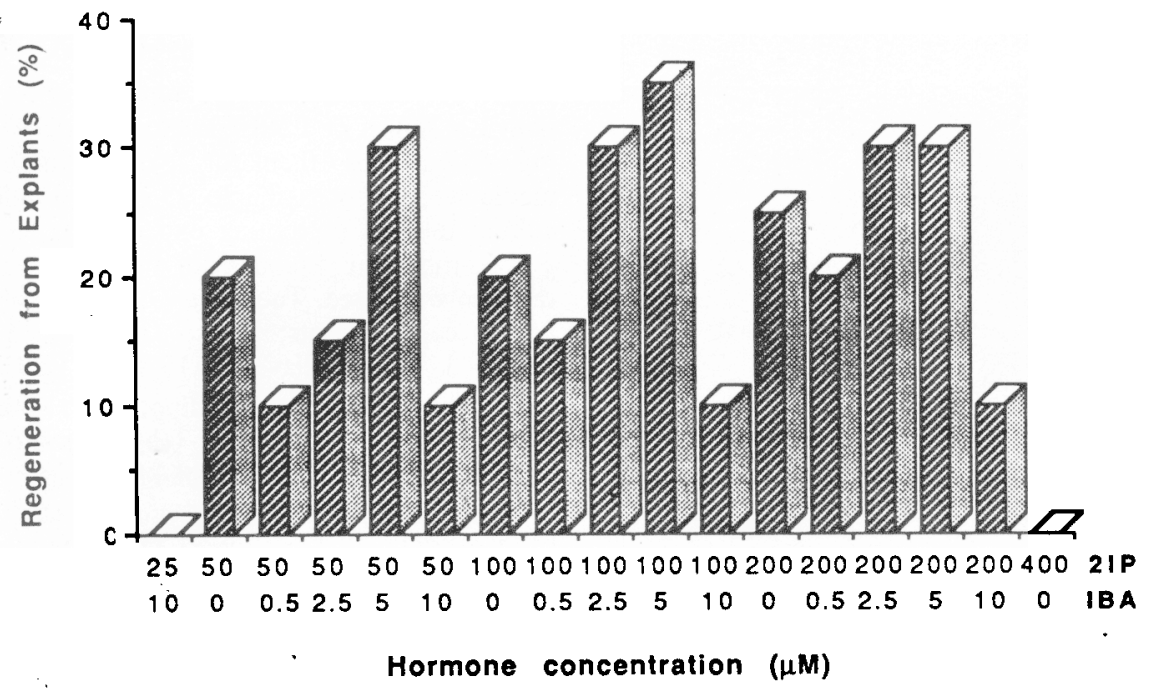

Fig. 3. Shoot regeneration from internodal stem explants derived from sprouted tubers of $A$. americana on the SIM-3 media series. No regeneration was observed with 0,25 , or $400 \mu \mathrm{M} 2 \mathrm{iP}$ with IBA. Each treatment was replicated 20 times. Data were collected after 18 weeks in culture.

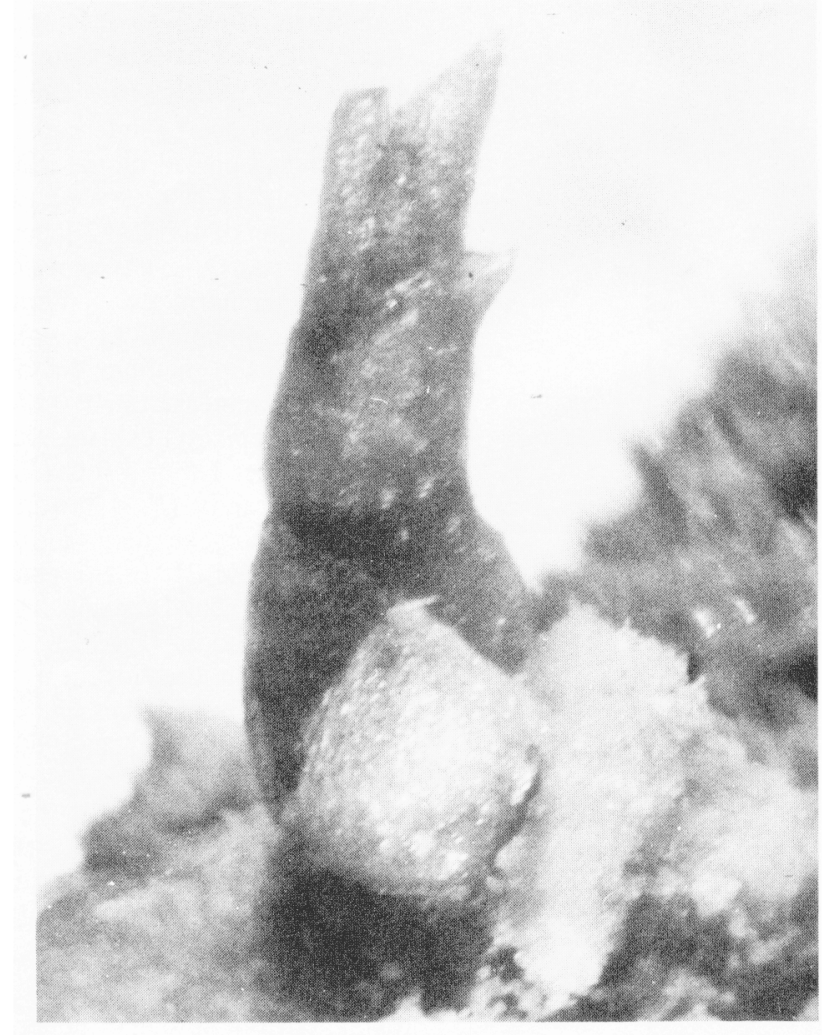

Fig. 4. An elongating shoot that regenerated from epicotyl-derived callus of $A$. americana $(\times 34)$.

Table 2. Effects of $\mathrm{GA}_{3}$ on $A$. americana epicotyl explants in the presence of $100 \mu \mathrm{M} 2 \mathrm{iP}$ and 0.5 $\mu \mathrm{M}$ IBA.

\begin{tabular}{|c|c|c|c|c|c|}
\hline \multirow[b]{2}{*}{$\begin{array}{l}\mathrm{GA}_{3} \\
(\mu \mathrm{M}) \\
\end{array}$} & \multicolumn{3}{|c|}{ No. explants ${ }^{\mathrm{z}}$} & \multicolumn{2}{|c|}{ Shoots } \\
\hline & Total & $\begin{array}{l}\text { Regenerating } \\
\text { shoots }\end{array}$ & $\begin{array}{c}\text { Regeneration } \\
(\%)^{\mathrm{y}}\end{array}$ & Total & $\begin{array}{c}\text { Mean per } \\
\text { explant } \pm \text { SE }\end{array}$ \\
\hline $\begin{array}{l}0.0 \\
1.5\end{array}$ & $\begin{array}{r}39 \\
166\end{array}$ & $\begin{array}{r}21 \\
111\end{array}$ & $\begin{array}{l}54 \mathrm{NS} \\
67 \mathrm{NS}\end{array}$ & $\begin{array}{r}33 \\
287\end{array}$ & $\begin{array}{l}1.6 \pm 0.7 \\
2.6 \pm 1.5\end{array}$ \\
\hline 3.0 & -67 & 41 & $61 \mathrm{NS}$ & 121 & $2.9 \pm 1.6$ \\
\hline
\end{tabular}

${ }^{2}$ Data collected after 16 weeks in culture.

y Nonsignificant $F$ statistic based on one-way analysis of variance.

proliferated nodal sections (Wickremesinhe et al., 1990), and from trifoliolate leaf explants from sprouted tubers (Wickreme- sinhe, 1988). These sources produced greenish callus from which shoots regenerated.

As has been observed with some other legumes, regeneration was possible only in the presence of high concentrations of cytokinins, ranging from 50 to $200 \mu \mathrm{M} 2 \mathrm{iP}$. Differentiation was mostly limited to primary callus, as has been reported with many legumes (Mathews, 1987). Regeneration from both epicotyl and sprouted tuber stem explants occurred in the presence of the original explant, and it was not possible to maintain regenerative callus over a long period by subculturing. Most workers have reported regeneration in legumes from adventitious meristems that originate from the epidermal and subepidermal cell layers, e.g., Pisum sativum (Hussey and Gunn, 1984), Lens culinaris (Williams and McHughen, 1986), and Glycine max (Wright et al., 1986). The age and size of the explants have been reported to be critical in the regeneration of shoots from Glycine canescens hypocotyl sections and from G. max primary leaf explants (Kameya and Widholm, 1981).

Regenerated shoots on the original medium were most obvious from the 10th week in epicotyl explants and the 12th week in sprouted tuber stem explants, with regeneration observed up to 20 weeks. Periodic subculturing was not necessary, and when performed, did not appreciably enhance regeneration. Shoots originated from green callus, proximal to the cut ends of the explants (Fig. 4). Actual cellular origins of the shoots are not known, as histological analyses were not performed. Epicotyl explants were superior to sprouted tuber stem explants with respect to the percentage of regenerated explants, time needed for regeneration, and the number of shoots per explant.

Occasional rooting was observed for developing shoots on regeneration media (SIM series), but this response was too infrequent to be used as an effective method to obtain rooted shoots. When regenerated shoots excised from internodal epicotyl explants were placed on RIB-1 media (Table 1), $70 \%$ to $80 \%$ of the regenerated shoots formed roots in the presence of 0.5 or $2.5 \mu \mathrm{M}$ IBA, with minimum callus formation.

In liquid rooting medium RIB-2, $\approx 90 \%$ of regenerated shoots from sprouted tuber stem and epicotyl explants rooted. Shoots from both sources responded similarly with respect to the percentage of rooted shoots and the percentage of shoots with at least one well-developed ( 5 to $10 \mathrm{~cm}$ long) root. About $50 \%$ of the shoots had sufficient roots for transfer to potting mix by 6 weeks. A greater percentage of the regenerated shoots produced roots $(\approx 90 \%$ vs. $75 \%)$ within a shorter period of time ( 6 weeks vs. 12 weeks) when placed on liquid than on solid media. The roots formed on liquid media were longer $(5-10 \mathrm{~cm})$ than roots formed on solid media (2-4 cm).

Dipping roots cleaned of agar in a 250 ppm Benlate solution, followed by an application of the same solution to the potting mix, increased the percentage of acclimated plants from $10 \%$ to $30 \%$. When shoots were rooted in liquid media and treated with Benlate, $60 \%$ of the plants survived. 
As improved lines of apios are developed, tissue culture involving explants originating from tuber selections will become more important, since one can then impose in vitro manipulations on improved germplasm.

\section{Literature Cited}

Beardsley, G. 1939. The groundnut as used by the Indians of eastern North America. Paper Michigan Acad. Sci. Arts Lett. 35:507-552.

Blackmon, W.J. and B.D. Reynolds. 1986. The crop potential of Apios americana-Preliminary evaluations. HortScience 21:1334-1336.

Hussey, G. and H.V. Gunn. 1984. Plant production in pea (Pisum sativum L. cvs. Puget and Upton) from long-term callus with superficial meristems. Plant Sci. Lett. 37: 143-148.

Kameya, T. and J. Widholm. 1981. Plant regen- eration from hypocotyl sections of Glycine species. Plant Sci. Lett. 21:289-294.

Mathews, H. 1987. Morphogenetic responses from in vitro cultured seedling explants of mung bean (Vigna radiata L. Wilczek). Plant Cell Tissue Organ Cult. 11:233-240.

Murashige, T. and F. Skoog. 1962. A revised medium for rapid growth and bioassays with tobacco tissue cultures. Physiol. Plant. 15:473497.

Reynolds, B.D., W.J. Blackmon, E. Wickremesinhe, M.H. Wells, and R.J. Constantin. 1990. Domestication of Apios americana, p. 436-442. In: J. Janick and H. Shands (eds.). Advances in new crops. Proc. First Natl. Symp. New Crops. Timber Press, Portland, Ore.

Thorpe, T.A. 1980. Organogenesis in vitro: Structural, physiological and biochemical aspects. Intl. Rev. Cyt. Suppl. 11A:71-111.
Wickremesinhe, E.R.M. 1988. In vitro regeneration and propagation systems for Apios americana Medikus. MS Thesis, Louisiana State Univ., Baton Rouge.

Wickremesinhe, E.R.M., W.J. Blackmon, and B.D. Reynolds. 1990. In vitro propagation of Apios americana. HortScience 25:1439-1440.

Williams, J.D. and A. McHughen. 1986. Plant regeneration of the legume Lens culinaris Medik. (lentil) in vitro. Plant Cell Tissue Organ cult. 7:149-153.

Woods, M. 1988. A revision of Apios and Cochlianthus (Leguminose). PhD Diss., Southern Illinois Univ., Carbondale.

Wright, M.S., S.M. Koehler, M.A. Hinchee, and M.G. Carries. 1986. Plant regeneration by organogenesis in Glycine max. Plant Cell Rpt. 5:150-154. 